\title{
CYCLIC VOLTAMMETRY OF SOME QUINOXALINE DI- $N$-OXIDES AND QUINOXALINES IN DIMETHYLFORMAMIDE
}

\author{
James R Ames, ${ }^{*}$ Melissa A Houghtaling and Deborah L Terrian \\ Department of Chemistry, University of Michigan-Flint, Flint, MI 48502, U S A
}

(Recewed 5 August 1991, in revised form 1 October 1991)

\begin{abstract}
The first cathodic reductions of two series of substituted quinoxaline $\mathrm{d}_{1}-N$-oxides and quinoxalınes in dimethylformamide were measured The effect of substituent on these reductions is reported and reversibility is discussed
\end{abstract}

Key words quinoxalıne- $N$-oxıdes, quinoxalınes, cyclıc voltammetry, reversibılity

\section{INTRODUCTION}

The electrochemical behavior of heteroaromatic amınes and heteroaromatic amıne- $N$-oxides, including quinoxaline $\mathrm{d}_{1}-\mathrm{N}$-oxides, has been studied in aqueous solutions[1-4] However, the studies of quinoxaline-1,4-dioxıdes in nonaqueous solvents are limited[5-9] Some of the investigations have examined alkyl or aryl substituents in the 2 - and the 2,3-positions We now expand the results of the prior work by surveying materials that contain a vanety of substituents attached adjacent to the nitrone functionalities

\section{EXPERIMENTAL}

Cyclic voltammetric $(c v)$ measurements were made using a Princeton Applied Research Corporation (PARC) model 264A Polarographic Analyser connected to a PARC model 303A SMDE, and a Yokogawa model 3022 A4 $X-Y$ recorder The reference electrode was a saturated calomel electrode (sce), separated from the working solution by a salt bridge filled with electrolyte, connected to the back panel reference electrode test point The internal silver wire in the electrode block was isolated from the test solution by covering it with an empty reference electrode jacket Scan rates employed ranged from 20 to $200 \mathrm{mV} \mathrm{s} \mathrm{s}^{-1}$, reported values are for a scan rate of $100 \mathrm{mV} \mathrm{s}^{-1}$ Solutions were $05 \mathrm{mM}$ in chromatographic grade dımethylformamide (Aldnch Chemıcal Co), containing $01 \mathrm{M}$ tetraethylammonium perchlorate (TEAP, G F Smith Chemical $\mathrm{Co}$ ) as the supporting electrolyte

Quinoxalıne-1,4-dioxides (1) and quinoxalınes (2) (Tables 1 and 2) were prepared and characterized $\left({ }^{1} \mathrm{H}-\mathrm{NMR}, u v-\mathrm{v} 1 \mathrm{~s}\right.$, and $\left.\mathrm{m} \mathrm{p}\right)$ by literature procedures $[10-20]$ with occasional modifications

*Author to whom correspondence should be addressed<smiles>[R]c1c([R])[n+]([O-])c2ccccc2[n+]1[O-]</smiles>

1<smiles>[R]c1nc2ccccc2nc1[R]</smiles>

2

\section{RESULTS AND DISCUSSION}

Representative cyclic voltammograms are given in Figs 1 and 2 The following methods were applied to analyze the $c v$ curves The Nicholson expression was used to calculate the ratio $t_{\mathrm{pa}} / t_{\mathrm{pc}}[21]$ The value of the half-wave potential was determined by the equation $E_{1 / 2}=\left(E_{\mathrm{pc}}+E_{\mathrm{pa}}\right) / 2$, which is in principle applicable to a reversible redox system[22] This equation gave $E_{1 / 2}$ values, for the first reduction wave, essentially independent of the sweep rate Cyclic voltammetry is also a measure of the reversibility of the electrode reaction $[1,23]$

Crawford and co-workers reported a value of $-121 \mathrm{~V}$ for quinoxaline-1,4-dioxide 1a[6], which will be used as the standard Incorporation of a 2-methyl group into the parent resulted in a more negative reduction potential, of compounds $1 \mathrm{a}$ and $1 \mathrm{~b}$ (Table 1) Addition of a second methyl group at position 3 makes the reduction more difficult by $70 \mathrm{mV}$ From the results in Table 1 it appears that each methyl group makes $E_{1 / 2}$ more negative by about $01 \mathrm{~V}$ The effect of an acyclic nng, fused at positions 2 and 3 , can be determined by comparing compounds lc, Id, and le Netther the presence of a nng nor its size appears to have a substantial consequence on the reduction peak Barqawı and Atfah found sımılar results in acetonitrile[8]

Alcohol if underwent a reversible one-electron reduction with $E_{1 / 2}=-127 \mathrm{~V}$ The radical anion, stable only at high scan rates, is less stable than that 
Table 1 Structures and cyclic voltammetry data of quinoxalıne-1,4-dioxıdes

\begin{tabular}{|c|c|c|c|c|c|}
\hline $\begin{array}{l}\text { Quinoxaline } \\
\text { di- } N \text {-oxide }\end{array}$ & $\mathbf{R}$ & $\mathbf{R}^{\prime}$ & $E_{1 / 2} / \mathrm{V}$ & $\Delta E_{\mathrm{p}} / \mathrm{mV}^{*}$ & $\begin{array}{c}\text { Reference for } \\
\text { preparation }\end{array}$ \\
\hline $\begin{array}{l}\text { la } \\
\text { lb } \\
\text { lc } \\
\text { ld } \\
\text { le } \\
\text { lf } \\
\text { lg } \\
1 \mathrm{~h} \\
11 \\
1 \mathrm{j} \\
\mathrm{lk} \\
\mathrm{lm} \\
1 \mathrm{~m} \\
10 \\
\mathrm{lp} \\
\text { lq }\end{array}$ & $\begin{array}{l}\mathrm{H} \\
\mathrm{H} \\
\mathrm{CH}_{3} \\
-\mathrm{CH}_{2} \mathrm{CH}_{2} \mathrm{CH}_{2^{-}} \\
-\mathrm{CH}_{2} \mathrm{CH}_{2} \mathrm{CH}_{2} \mathrm{CH}_{2}- \\
\mathrm{CH}_{3} \\
\mathrm{CH}_{2} \mathrm{OH} \\
\mathrm{CH}_{3} \\
\mathrm{H} \\
\mathrm{Ph} \\
\mathrm{Ph} \\
\mathrm{H} \\
\mathrm{CH}_{3} \\
\mathrm{CH}_{3} \\
\mathrm{Ph} \\
\mathrm{CH}_{3}\end{array}$ & $\begin{array}{l}\mathrm{H} \\
\mathrm{CH}_{3} \\
\mathrm{CH}_{3} \\
\\
\mathrm{CH}_{2} \mathrm{OH} \\
\mathrm{CH}_{2} \mathrm{OH} \\
\mathrm{CH}_{2} \mathrm{OCOCH}{ }_{3} \\
\mathrm{Ph} \\
\mathrm{Ph} \\
\mathrm{CH}_{2} \mathrm{Ph} \\
\mathrm{CF}_{3} \\
\mathrm{COCH}_{3} \\
\mathrm{CO}_{2} \mathrm{CH}_{3} \\
\mathrm{COPh} \mathrm{COPh}^{-}\end{array}$ & 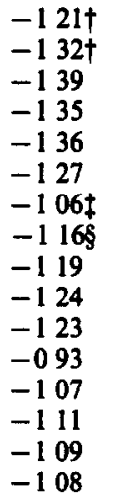 & $\begin{array}{l}70 \\
80 \\
75 \\
70 \\
80 \\
\frac{70}{70} \\
70 \\
70 \\
80 \\
65 \\
70 \\
75 \\
70 \\
75\end{array}$ & $\begin{array}{l}- \\
\overline{-} \\
{[10]} \\
{[11]} \\
{[11]} \\
{[12]} \\
-[12] \\
{[13]} \\
{[14]} \\
{[14]} \\
{[15]} \\
{[13]} \\
{[14]} \\
{[13]} \\
{[16]}\end{array}$ \\
\hline $\begin{array}{l}{ }^{*} \Delta E_{\mathrm{p}}=\mid E_{\mathrm{pa}}- \\
+\operatorname{Ref}[6] \\
+\operatorname{Ref}[5] \\
\text { SIrreversible v } \\
\mid E_{\mathrm{pp} / 2} \text { value }\end{array}$ & $E_{\mathrm{p}}, 100 \mathrm{mV} \mathrm{s}^{-1}$ & & & & \\
\hline
\end{tabular}

of the dimethyl The inductive effect of the hydroxyl and hydrogen bonding with $N$-oxide can be used to rationalize the greater ease of reduction for If vs 1c Hydrogen bonding enhances the positive nature of the nitrogen, thus increasing electron attracting ability and stabilizing the oxyanions formed during charge transfer, the first reduction is due to the reduction of the $N$-oxide functionality, to form the radical anion The diol $1 \mathrm{~g}$ reduced at $-106 \mathrm{~V}[5]$ Evidently the addition of the second alcohol functionality influences the reduction more than the first

Acetate $1 \mathrm{~h}$ had an $E_{\mathrm{p}}$ which was $019 \mathrm{~V}$ more positive than $1 \mathrm{c}$, and gave an irreversible wave The greater ease of electron uptake follows from the presence of the electronegative acetate group The correspondence with alcohol is evident Ryan et al [5] suggested the effect of the ester molety might be further enhanced by the interaction with nitrone as in structure 3 Earlier workers associated the ease of reduction of acetate substituted quinoxaline $N$-oxides with the liability of the methylene protons[9]<smiles></smiles>

The effect of an aromatic substituent can be determined by comparing compounds $1 \mathrm{a}, 1_{1}$ and $1 \mathrm{~J}$ 2-Phenylquinoxaline-1,4-dioxide produced $E_{1 / 2}$ of $-119 \mathrm{~V}$ As a first approximation, it may be expected that incorporation of a second phenyl substituent would facilitate reduction as evidenced in prior studies[24] However, compound 1] generated an $E_{1 / 2}$ of $-124 \mathrm{~V}$, in agreement with Crawford et al [6] The results may be rationalized by steric

Table 2 Structures and cyclic voltammetry data of quinoxalınes

\begin{tabular}{|c|c|c|c|c|c|}
\hline Quinoxaline & $\mathbf{R}$ & $\mathbf{R}^{\prime}$ & $E_{1 / 2} / \mathrm{V}$ & $\Delta E_{\mathrm{p}} / \mathrm{mV}^{*}$ & $\begin{array}{c}\text { Reference for } \\
\text { preparation }\end{array}$ \\
\hline $\begin{array}{l}2 \mathrm{a} \\
2 \mathrm{~b} \\
2 \mathrm{c} \\
2 \mathrm{~d} \\
2 \mathrm{e} \\
2 \mathrm{f} \\
2 \mathrm{~g} \\
2 \mathrm{~h} \\
2 \mathrm{l}\end{array}$ & $\begin{array}{l}\mathrm{H} \\
\mathrm{H} \\
\mathrm{CH}_{3} \\
-\mathrm{CH}_{2} \mathrm{CH}_{2} \mathrm{CH}_{2} \mathrm{CH}_{2}- \\
\mathrm{H} \\
\mathrm{Ph} \\
\mathrm{Ph} \\
\mathrm{CH}_{3} \\
\mathrm{Ph}\end{array}$ & $\begin{array}{l}\mathrm{H} \\
\mathrm{CH}_{3} \\
\mathrm{CH}_{3} \\
\\
\mathrm{Ph} \\
\mathrm{Ph} \\
\mathrm{CH}_{2} \mathrm{Ph} \\
\mathrm{COCH}_{3} \\
\mathrm{COPh}\end{array}$ & $\begin{array}{l}-180 \dagger \\
-171 \dagger \\
-187 \ddagger \\
-154 \\
-154 \\
-155 \\
-160 \ddagger \\
-128 \\
-128\end{array}$ & $\begin{array}{l}- \\
\overline{708} \\
80 \\
80 \\
85 \\
658 \\
75 \\
75\end{array}$ & $\begin{array}{c}- \\
- \\
\text { commercial } \\
{[17]} \\
{[18]} \\
{[19]} \\
{[17]} \\
{[20]} \\
{[13]}\end{array}$ \\
\hline $\begin{array}{l}E_{\mathrm{p}}=\mid E_{\mathrm{pa}} \\
\text { ef [6] } \\
\text { uasirevers } \\
\text { value }\end{array}$ & ave, $E_{p}, 100 \mathrm{~m}$ & & & & \\
\hline
\end{tabular}




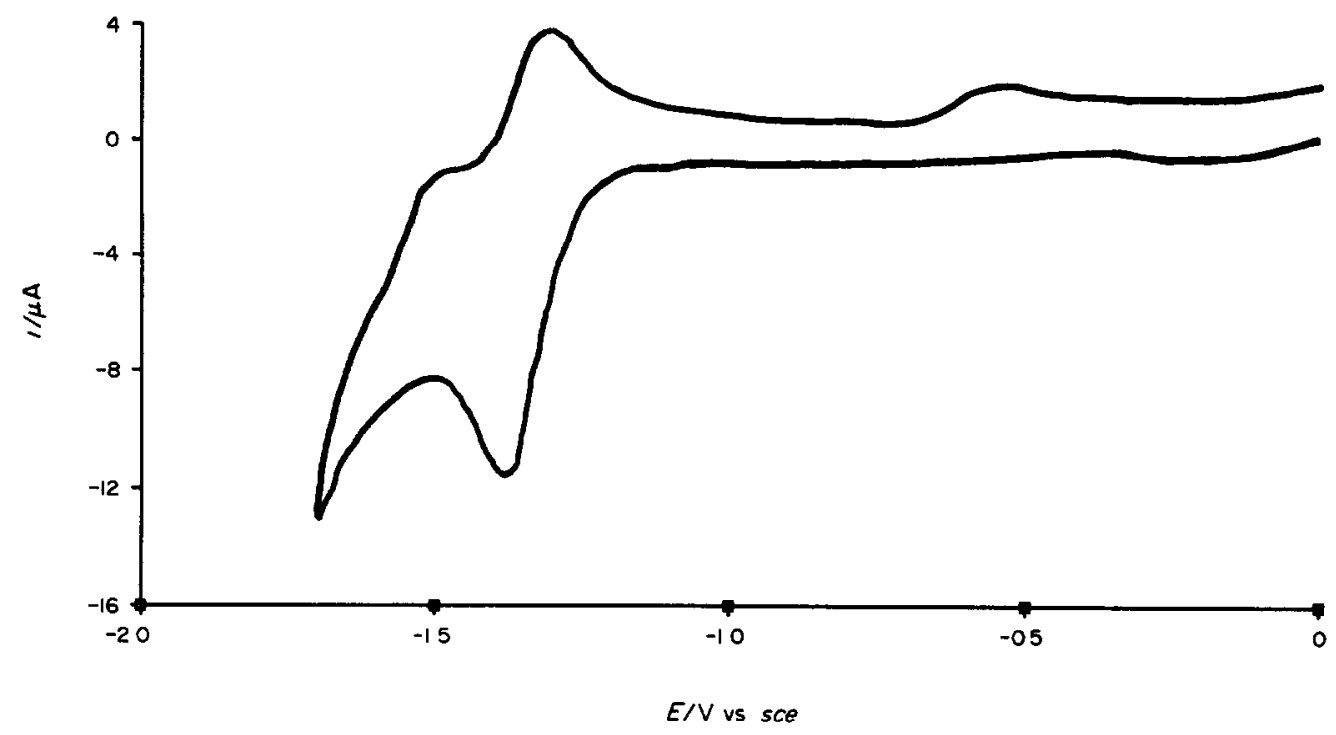

Fig 1 Cyclic voltammogram of $1 \mathrm{~d}$ in dimethylformamide containing $01 \mathrm{M}$ TEAP supportıng electrolyte, $01 \mathrm{Vs}^{-1}$

effects The potential exists for sufficient orbital overlap between nucleus and phenyl ring in 11 such that the anion radical generated after electron uptake may be stabilized by delocalization Thus, reduction occurs at a slightly more positive potential than in compound la Apparently, this effect is lessened for the 2,3-diphenyl material due to the added steric interference resulting from crowding by the two aromatic groups[25] Hayashı and co-workers have stated that the conjugation between the phenyl group and the quinoxaline ring is lessened by the presence of bulky substituents on the adjacent carbon[26] Estımates from molecular mechanics calculations (made by using the programs PC model and MMX, avallable from Serena Software, Bloomington, Ind1ana) for the dihedral angle between the diazine nucleus and the phenyl ning indicate that the value is about $10^{\circ}$ larger in the diphenyl material, $2 e 10^{\circ}$ farther from coplanarity Both compounds reduce at potentials more positive than their methyl analogs
Thus, the phenyl substituent acts as an electron-withdrawing group Zuman has suggested that differences observed with phenyl and other substituents are predominantly due to a polar effect[27] There is little change in reduction potential when a methylene group is inserted between the heteroaromatic and phenyl nings as in compound $1 \mathrm{k}$ Therefore, sterics do appear to affect reduction

Examination of quinoxaline dioxides with other electron withdrawing substituents attached in the 2- and the 2,3-positions resulted in more positive reduction potentials than the alkyl substituted materials For example, 2-trifluoromethylquinoxaline-1,4-dioxide reduced at a potential about $400 \mathrm{mV}$ more positive than compound $\mathbf{1 b}$ Fieser and Fieser have reported a positive shift in reduction potential upon substitution of halogen for hydrogen[28]

The replacement of a methyl group with an acetyl group as in compound in caused about a $03 \mathrm{~V}$ increase in the reduction value The result for the

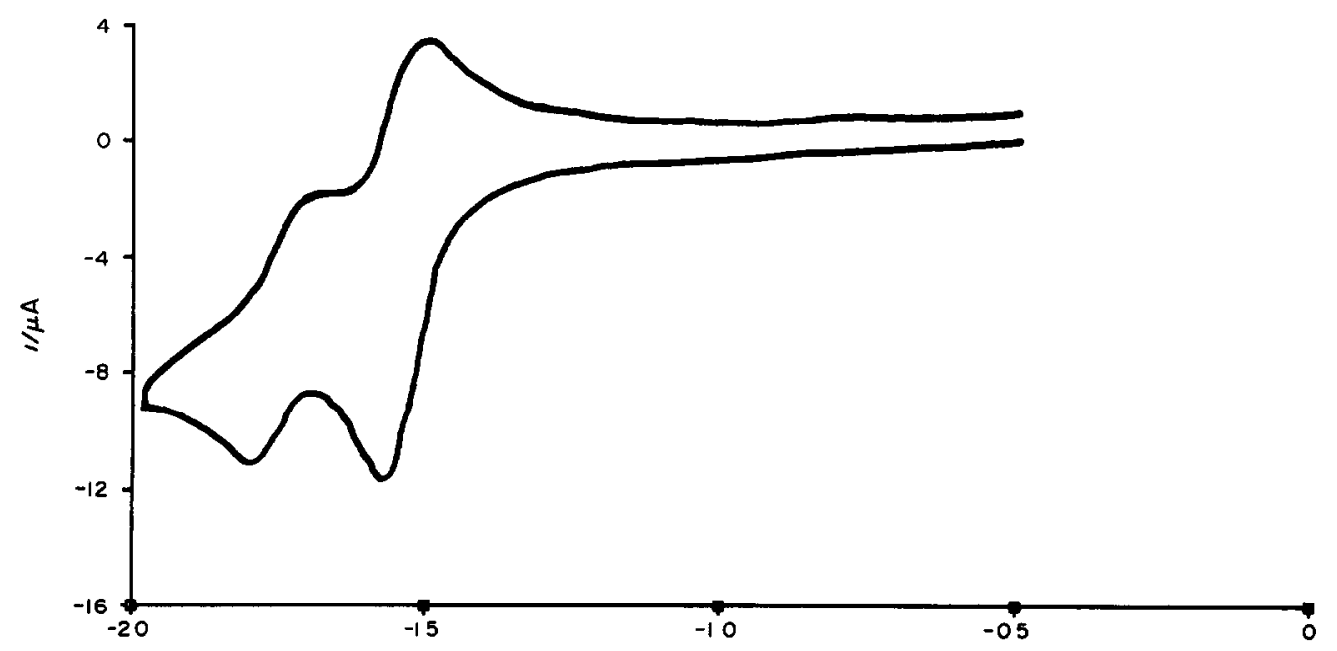

Fig 2 Cyclic voltammogram of $2 \mathrm{~d}$ in dimethylformamide contaning $01 \mathrm{M}$ TEAP supporting electrolyte, $01 \mathrm{Vs}^{-1}$ 
ester 10 is only slightly more negative than ketone Ester and ketone functionalities have approximately the same electron-withdrawing ability[29] A similar situation exists for phenyl and benzoyl, cf $1 \mathrm{l}$ and $\mathrm{lp}$, although the difference in potentials is only about $150 \mathrm{mV}$ Perhaps steric interactions do not allow for conjugation between carbonyl or phenyl and heterocyclic nng as proposed for the diphenyl compound (vide supra) Further support comes from 2-benzoyl-3-methylquinoxaline-1,4-diox1 de, $1 \mathrm{~g}$ which reduced at an $E_{1 / 2}$ of $-108 \mathrm{~V}$ The methyl group is apparently large enough to reduce orbital overlap

The reduction in the quinoxaline series (Table 2) is due to the formation of a radical anion It is clear that the reduction is more difficult than in the $\mathrm{d}_{1}-N$-oxides This is likely to be due to the coordinated oxygen atoms in the nitrones, which make the quinoxaline rung more electrophilic and provide increased resonance stabilization of the radical anion[30] Electron uptake depends on the electrophilicity of the material being reduced and the stability of the radical produced[31]

A similar trend in reduction potentials for the diazines as the dioxides can be observed in Table 2 Electron releasing groups yield more negative values than electron withdrawing substituents, te compounds $2 \mathrm{~h}$ and $2 \mathrm{i}$ reduced approximately $300 \mathrm{mV}$ more positive than the others Data for compound $2 \mathrm{~d}$ is somewhat surprising since the value is more positive than compound $2 \mathrm{c}$ and close to those for the phenyl substituted materials This was not observed with the dioxides, the reasons for this are unknown to us

The reversibility of the reductions may be discussed using the $\Delta E_{\mathrm{p}}$ and $t_{\mathrm{pa}} / l_{\mathrm{pc}}$ values The difference between peak potentials for $1 \mathrm{~m}$ was close to theoretical for a one-electron reversible process, whereas the others were somewhat higher, ranging from 70 to $85 \mathrm{mV}$, and independent of the scan rate The calculated $l_{\mathrm{pa}} / l_{\mathrm{pc}}$ values for all dioxides except $1 \mathrm{f}$ were close to unity, deviating only slightly at slower scan rates, indicating the formation of a relatively stable reduction product Evidently a slow irreversible reaction takes place after electron uptake with if The voltammograms for compound ih had an $\left|E_{\mathrm{p}}-E_{\mathrm{p} / 2}\right|$ value of $70 \mathrm{mV}$, thus implying electron transfer accompanied by fast follow-up chemistry A prior investigation of several of the current samples in acetonitrile noted a dependence of the reversibility of the first wave on the switching potential and the scan rate[8] Results from the unoxidized compounds were somewhat different Although the separation between forward and reverse scans was about $80 \mathrm{mV}$, the current ratio for compounds $2 \mathrm{~d}-\mathrm{f}$ deviated significantly from one, generally ranging from 06 to 08 Apparently, kinetic or other complications occur in the electrode process Compounds $2 \mathrm{~h}$ and 21 produced values greater than 095

In summary, groups which lower the reduction potential of the parent are generally those which facilitate substitution in an aromatic nng, eg benzene, and those which increase the reduction potential have the opposite effect and retard aromatic subst1tution

\section{REFERENCES}

1 K B Wiberg and T P Lew1s, J Am chem Soc 92,7154 (1970)

2 G Horn, W Schulze and D Tresselt, $J$ prakt Chem 327,156 (1985)

3 Y K ${ }_{1}$ danı, K Ohıra and H Koike, Yakugaku Zassh 93 , 157 (1973)

4 S C Leach, R D Weaver, K Kınoshita and W W Lee, $J$ electroanal Chem 129, 213 (1981)

5 M D Ryan, $R$ G Scamehorn and $P$ Kovacic, $J$ pharmaceut $S c l$ 74, 492 (1985)

6 P W Crawford, R G Scamehorn, U Hollstein, M D Ryan and P Kovacic, Chem-Biol Interactions 60, 67 (1986)

7 H Miyazakı, Y Matsuhisa and T Kubota, Bull Chem Soc Jpn 54, 3850 (1981)

8 K R Barqawı and M A Atfah, Electrochim Acta 32 , 597 (1987)

9 V M Kazakova, O G Sokol, G G Dvoryantseva, I S Musatova and A S Elına, Chem Heterocycl Comp 16, 284 (1980)

10 K Ley, F Seng, U Eholzer, R Nast and R Schubart, Angew Chem Int Edn Eng 8, 596 (1969)

$11 \mathrm{M} J$ Haddadın and C H Issidondes, Tetrahedron Let 36, 3253 (1965)

12 M L Edwards, R E Bamburg and $H$ W Rıtter, $J$ med Chem 18, 637 (1975)

13 C H Issidorides and M J Haddadın, $J$ org Chem 31, 4067 (1966)

14 D L Ternan, M A Houghtaling and J R Ames, $J$ Chem Educ (in press)

15 E Abushanab, $J$ Am chem Soc 93, 6532 (1971)

16 M J Haddadin. M U Taha, A A Jarrar and C H Issidonides, Tetrahedron 32, 719 (1976)

17 M J Haddadin, G E Zahr, T N Rawdah, N C Chelhot and C H Issidondes, Tetrahedron 30, 659 (1974)

18 G R Proctor and M A Rehman, J chem Soc, C, 2696 (1967)

19 K L Willamson, Macroscale and Microscale Organic Experuments, p 540 D C Heath, Lexington, MA (1989)

20 J P Dirlam and J W McFarland, J org Chem 42, 1360 (1977)

21 A J Bard and L R Faulkner, Electrochemical Methods, p 229 Wiley, New York (1980)

22 S F Nelsen, V Peacock and G R Wetsman, $J$ Am chem Soc 98, 5269 (1976)

23 A J Fry, Synthetic Organic Electrochemistry, 2nd Edn, p 50 Wiley, New York (1989)

24 P Zuman, Substituent Effects in Organic Polarography, 3 Plenum Press, New York (1967)

25 P Zuman, Substituent Effects in Organic Polarography, pp 85-94 Plenum Press, New York (1967)

26 E Hayashi, C Iıjıma and K Yamamoto, Yakugaku Zassh 86, 1109 (1966), Chem Abstr 67, 3066 (1967)

27 P Zuman, Substituent Effects in Organic Polarography, pp 192-194 Plenum Press, New York (1967)

28 L F Fieser and M Fieser, $J$ Am chem Soc 57, 491 (1935)

29 J March, Advanced Organic Chemistry, 3rd Edn, p 17 p 238 Wiley, New York (1985)

30 W Kalm, Angew Chem Int Edn Engl 22, 171 (1983)

31 V P Kadysh, Y P Stradyn, E S Lavrinovich and P P Zann, Chem Heterocycl Comp 11, 588 (1975) 